\title{
Coal Moisture Variations in Response to Rainfall Event in Mines and Coal-Fired Power Plant Stockpiles-Part 1: Runoff, Infiltration, and Drainage
}

\author{
Quentin Peter Campbell (D), Marco le Roux and Fardis Nakhaei *(D)
}

Citation: Campbell, Q.P.; le Roux, M.; Nakhaei, F. Coal Moisture Variations in Response to Rainfall Event in Mines and Coal-Fired Power Plant Stockpiles-Part 1: Runoff, Infiltration, and Drainage. Minerals 2021, 11, 1365. https://doi.org/ $10.3390 / \min 11121365$

Academic Editor: Carlito Tabelin

Received: 20 October 2021

Accepted: 17 November 2021

Published: 3 December 2021

Publisher's Note: MDPI stays neutral with regard to jurisdictional claims in published maps and institutional affiliations.

Copyright: (c) 2021 by the authors. Licensee MDPI, Basel, Switzerland. This article is an open access article distributed under the terms and conditions of the Creative Commons Attribution (CC BY) license (https:/ / creativecommons.org/licenses/by/ $4.0 /)$.
School of Chemical and Minerals Engineering, North-West University, Potchefstroom 2531, South Africa; quentin.campbell@nwu.ac.za (Q.P.C.); Marco.LeRoux@nwu.ac.za (M.1.R.)

* Correspondence: 36598704@nwu.ac.za; Tel.: +27-661-031-248

\begin{abstract}
Excessive coal moisture leads to a lower heating value and power plant efficiency, and increased transportation costs. Therefore, coal stockpile management and moisture control are particularly important in regions with heavy precipitation. This paper and Part 2 address factors influencing moisture retention and migration in coal stockpiles. Part 1 of this paper series simulates phenomena of runoff, infiltration, and drainage in a stockpile after a rainfall event. Part 2 reports the effect of coal particle size and climate conditions on the rate and depth of moisture evaporation process within a coal stockpile. To perform this study, two coal samples were collected from the Witbank mine in South Africa. The results of the present study showed that smaller interparticulate void spaces because of the compaction or fines particles $(-0.5 \mathrm{~mm}$ fraction) inhibited infiltration, leading to increased runoff volume. An increase stockpile slope increased the amount of runoff due to coal-water contact time reduction. The ability of heavy rainfall to destroy near-surface structures (erosion) happened more readily at stockpiles with high slopes and high fine content. The fine content significantly influenced the dewatering efficiency of drainage. Coals with higher ash contents had stronger moisture retention ability than that of other coals even though coals with low ash contents had a high fine content. This was ascribed to the contribution of the clay minerals, such as kaolinite, in the high ash coal. The results of this paper can be used for the effective management of coal stockpiles to prevent excessive moisture in stockpiles for the best possible utilisation of coal in power plants.
\end{abstract}

Keywords: coal stockpile; rainfall; simulation; moisture; gravity drainage; runoff; infiltration

\section{Introduction \\ 1.1. Background}

Coal, a key fuel, is still one of the most essential energy sources in the world, accounting for more than $70 \%$ of disposable energy consumption [1,2]. South Africa, the sixth largest coal-producing country, has coal reserves estimated at 50 billion tonnes [3]. In 2016, South Africa produced $277 \mathrm{Mt}$ of coal, of which $190 \mathrm{Mt}$ was internally sold, while $87 \mathrm{Mt}$ was exported. Around $77 \%$ of mined coal is consumed to supply energy to the country in the form of electricity and synthetic fuels. More than $92 \%$ of the electricity in South Africa is generated by coal-fired power stations [4].

To ensure smooth operation, coals are usually stockpiled in open storage yards (50,000-200,000 tons). As coal producers and consumers experience pressure to increase throughput, retention times on stockpiles are shortened [5]. It is, therefore, important to optimally manage stockpiles.

Moisture content is a key index of coal quality that influences both the physical and chemical characteristics of coal, and it is required for determining the calorific value and handling properties of coal [6-8]. Moisture content can change depending on time and weather conditions. High moisture content in coal leads to increased transportation costs 
as a result of the decreased heating value of the coal $[9,10]$, and handling problems $[7,11]$. Client contract details vary, but total moisture specifications around $8 \%$ to $9 \%$ are common. A high moisture content typically results from excessive rain, surface water in the raw coal, inadequate clay removal, or poor plant dewatering practices for washed coals.

During rainy seasons, the moisture content of coal in a mine or power-plant stockpile can increase and even reach saturation levels [12]. The process of moisture migration in coal stockpiles is complicated, but it must be properly understood to improve the control of moisture in stockpiles. Factors influencing moisture control on stockpiles are mineral content, porosity, stockpile height and slope, particle size distribution, weather conditions, and compaction rate $[8,13]$. These are important considerations to determine a stockpile management strategy [14].

Although several studies reported on the drying and thermal treatment of coals $[15,16]$, few so far studied comprehensive changes in coal stockpile behaviour after rainfall and the control of coal moisture in stockpiles. As this type of research requires longer periods of time and more budget, the literature is lacking in this regard. Curran et al. experimented on coal stockpiles with rainwater systems to determine surface runoff and infiltration rates. This research suggested that the optimal slope for stockpiles should be determined to minimise water contact time, while preventing mass slumping and rill erosion from occurring [13]. Goede et al. investigated the evaporation rate of moisture from a coal stockpile surface [17]. This work showed that the particle size of a coal bed affects the rate of evaporation, and that the porous structure of coarse coal contributes to the process. Moisture initially evaporates at a higher rate from a stockpile containing fine particles than ones with coarser particles, but it is limited to the outer shell of the coal stockpile. For coarse particles, the porous structure increases the depth at which evaporation occurs.

Since it is difficult to evaluate multiple factors when investigating water movement in coal stockpiles, most previous studies only focused on one or two factors. It is still not clear how coal moisture content changes over time following different precipitation rates, and which the key parameters are that specify these changes. It is indispensable to understand multifactor effects on moisture migration patterns to estimate moisture content within coal stockpiles, especially in regions with heavy rainfall.

Accordingly, to overcome the various limitations found in the literature, this research paper analyses the behaviour of water within a simulated coal stockpile to better understand the mechanisms by which water is transported by focusing on the effects of particle size distribution, weather conditions, coal type, degree of compaction, and stockpile height. To accomplish this, a two-part paper is presented. Part 1, the current paper, consists of the mechanisms of runoff, infiltration, and drainage within a coal stockpile after rainfall. In Part 2, the effect of coal particle size and ambient conditions on the rate and depth of moisture evaporation within a stockpile is investigated.

\subsection{Mechanics of Water Movement in Stockpiles}

A coal stockpile consists of a heterogeneous distribution of porous coal particles, water, and gaseous types such as air and water vapour in interparticle channels and the microstructures of particles [18]. Considering only extraneous water addition, such as rain, for this study, there are four mechanisms of water movement in coal stockpiles. When the rain falls on a stockpile, it either runs off the surface or infiltrates. The infiltrated water can evaporate, drain, or stay within the stockpile [14]. Figure 1 is a schematic illustration of these mechanisms.

The relationship between coal stockpile runoff and infiltration depends on factors such as particle size distribution, rainfall intensity, weather conditions, clay mineral content, initial moisture content, and the degree of compaction of the stockpile bed $[13,19]$. 


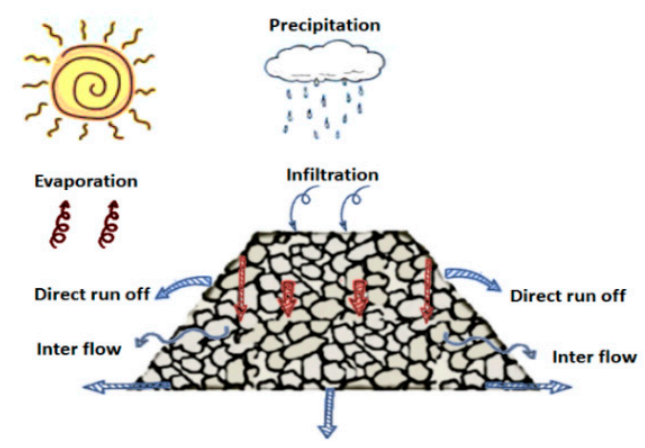

Figure 1. Hydrological cycle of a coal stockpile.

\section{Experimental Methods}

\subsection{Materials}

During this investigation, two coal samples obtained from the Witbank region of South Africa were studied. Coal A (typical power station feedstock coal) was a mixture of washed nos. 2 and no. 4 seam coals, while Coal B was washed no. 2 seam export coal. Particle size analysis indicated that Coals $A$ and $B$ both had size ranges of -53 to $0 \mathrm{~mm}$. The $\mathrm{d}_{50}$ of Coals A and B was similar $(13.5 \mathrm{~mm})$. The $\mathrm{d}_{20}$ values of Samples A and B were 0.9 and $1.4 \mathrm{~mm}$, respectively.

The proximate analysis and calorific values of the samples are given in Table 1. Tests were performed on an air-dried basis by an external accredited laboratory. As Coals A and B had similar inherent moisture contents, comparable porosities could also be assumed. Crystalline phases were investigated by powder XRD technique (Rietveld method). This analysis did not account for any species in the amorphous phase, but only the crystalline phase. Mineral abundances are shown in Table 2.

Table 1. Proximate analysis of coal samples.

\begin{tabular}{cccc}
\hline Parameters & Coal A & Coal B & Standard \\
\hline Inherent moisture content $(\%)$ & 2.5 & 2.6 & ISO 11722: 1999 \\
Ash content $(\%)$ & 35.6 & 15.9 & ISO 1171: 2010 \\
Volatile matter $(\%)$ & 19.0 & 25.2 & ISO 562: 2010 \\
Fixed carbon $(\%)$ & 42.9 & 56.4 & -N / A \\
Gross Calorific Value (CV) $(\mathrm{MJ} / \mathrm{kg})$ & 19.24 & 26.89 & ISO 1928: 2009 \\
Grade (based on CV) & Grade D-III & Grade B & CKS 561-1982 \\
\hline
\end{tabular}

Table 2. XRD analysis of coal samples.

\begin{tabular}{ccc}
\hline \multirow{2}{*}{ Mineral } & \multicolumn{3}{c}{ Weight (\%) } \\
\cline { 2 - 3 } & Coal A & Coal B \\
\hline Calcite & 0.43 & 1.14 \\
Dolomite & 0.42 & 0.97 \\
Graphite & 66.15 & 83.29 \\
Gypsum & 1.79 & 0.11 \\
Hematite & 0.33 & 0.00 \\
Kaolinite & 21.85 & 12.66 \\
Muscovite & 2.25 & 0.79 \\
Pyrite & 0.71 & 0.17 \\
Quartz & 5.91 & 0.89 \\
Siderite & 0.16 & 0.00 \\
\hline
\end{tabular}

\subsection{Method and Site Description}

In the present study, the tests incorporated three water transport processes: runoff, infiltration, and drainage. Evaporation results are presented in Part 2 of this study. 


\subsubsection{Runoff and Infiltration}

Experiments were carried out to investigate the water runoff and infiltration ratios as a result of stockpile configuration, coal particle size, and rainfall intensity. Experiments were performed on a rig consisting of a variable-angle rectangular container with an overhead rain system, shown in Figure 2. The dimensions of the coal container were $1.24 \mathrm{~m} \times 0.50 \mathrm{~m} \times 0.55 \mathrm{~m}$, and could be set at angles of $0^{\circ}, 20^{\circ}, 30^{\circ}$, and $38^{\circ}$ to the horizontal. Rainfall was simulated with the use of plastic containers over the setup. Each container had several $0.1 \mathrm{~mm}$ holes at the bottom, and was equipped with a float-ball valve to ensure a constant water level in the water tank and rainfall uniformity. Runoff water accumulated in the gutter and was removed through an outlet. The infiltrated water was removed by an outlet value at the bottom of the container, and the runoff water was collected in an overflow weir. To prevent the loss of coal particles through the bottom outlet, a metal mesh layer was installed just before this valve. The volumes of the infiltrated and runoff water collected over a certain time were noted.

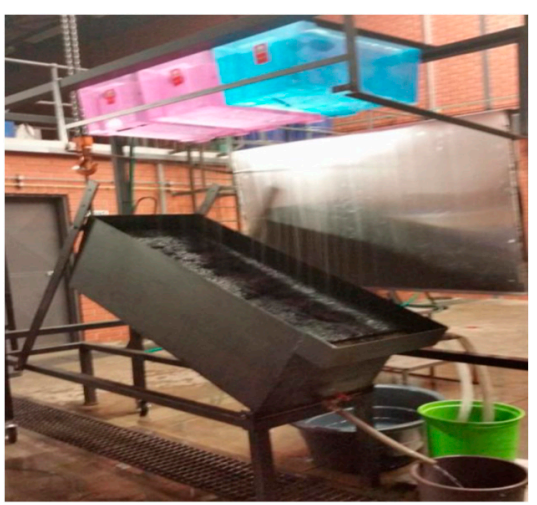

Figure 2. Runoff versus infiltration experimental setup.

Coal from Sample B was loaded into the container. Where required, some coal beds were prepared by loading a certain amount of coal into the container and compacting it until a certain degree of compaction (defined by the bulk density of the sample) was obtained. To ensure that the degree of compaction was homogeneous throughout the coal bed, the bed was compacted layer by layer. The thickness of each layer was measured after mechanical pressure had been applied to compact the layer to a predetermined fraction of the initial thickness. The coal bed had been saturated with water prior to being subjected to rainfall to ensure that the experiments were conducted at steady-state conditions. The box was then set to the desired angle, and the simulated rain event was started. This procedure was repeated three times for each of the experimental conditions given in Table 3, and results are presented as averages. Overall, 46 runs were performed.

Table 3. Summary of experimental runoff versus infiltration conditions.

\begin{tabular}{ccc}
\hline Rainfall Intensity $(\mathbf{m m} / \mathbf{h})$ & Slope Angle $\left(^{\circ}\right)$ & Size Range $(\mathbf{m m})$ \\
\hline & Without compaction $\left(\rho=997 \mathrm{~kg} / \mathrm{m}^{3}\right)$ \\
\hline 20-30-38 & $(-53+6.7),(-53+0),(-6.7+0)$ \\
\hline & With compaction $\left(\rho=1069-1157 \mathrm{~kg} / \mathrm{m}^{3}\right)$ \\
\hline $174-220-290$ & $20-30-38$ & $(-53+0)$ \\
\hline
\end{tabular}

\subsubsection{Gravity Drainage}

The drainage characteristics of a coal stockpile are primarily influenced by the coal type, particle size, existence of fines layers, the extent of compaction, and the height of the stockpile. To investigate these factors, two different drainage columns $(0.5$ and $2.0 \mathrm{~m}$ high) were used (Figure 3). The columns had an interior diameter of $0.38 \mathrm{~m}$ and were fitted 
with a screen at the bottom that supported the packed coal bed. Coal samples were loaded into the columns according to the conditions listed in Table 4. For all runs, $20 \mathrm{~L}$ of water was added in one step to the top of the columns to percolate through the coal bed to be collected at the bottom.

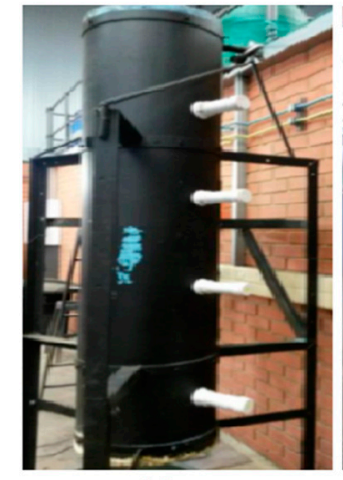

(a)

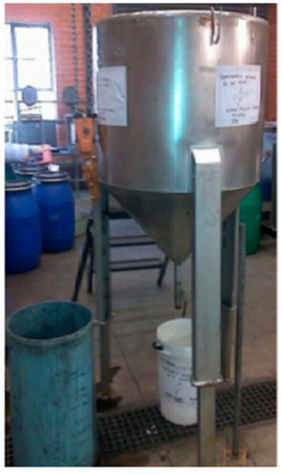

(b)

Figure 3. Drainage column experimental setup: (a) $2 \mathrm{~m}$ height; (b) $0.48 \mathrm{~m}$ height.

Table 4. Summary of experimental drainage conditions.

\begin{tabular}{ccccc}
\hline Column Height $(\mathbf{m})$ & Coal Type & Size Range $(\mathbf{m m})$ & $\boldsymbol{\rho}\left(\mathbf{k g} / \mathbf{m}^{\mathbf{3}}\right)$ & Layer of Fines $(-\mathbf{0 . 5} \mathbf{~ m m})$ \\
\hline 0.48 & A & $(-53+0) ;(-53+0.5)$ & $1073-1198-1288$ & $0-3-6 \mathrm{~cm}$ \\
2 & A & $(-53+0) ;(-53+0.5) ;(-53+1)$ & 1073 & Without layer of fines \\
2 & B & $(-53+0) ;(-53+6.7) ;(-6.7+0)$ & 1069 & Without layer of fines \\
\hline
\end{tabular}

For the $2 \mathrm{~m}$ high column, the mass of water that percolated through the bed was continuously weighed on a load cell. This column was also equipped with four sampling ports on the side of the column, from which samples were taken every other day to track the migration of moisture and fine coal content over time.

The $0.5 \mathrm{~m}$ high column was operated in a batch mode, and the drained water was weighed only once after all drainage had ceased. Here, the coal bed was only sampled during the dismantling of the bed once drainage had ceased. A layer of fine particles was added to the middle of the drainage column, as described in Table 4. Gravity drainage columns tests were repeated two or three times, and an average value is reported.

\section{Results and Discussion}

\subsection{Runoff}

\subsubsection{Effect of Rainfall Intensity}

Figure 4 shows that the measured runoff proportion (as a fraction of the total water addition) is highly dependent on rainfall intensity in general, with an increase in rainfall intensity leading to a greater runoff proportion. Similar results were found in other studies [13,20-22]. In the bed of mixed particles with a size range of -53 to $0 \mathrm{~mm}$, the increase in runoff rate was much more pronounced than that in other particle size ranges. The -53 to $6.7 \mathrm{~mm}$ particles caused no runoff, since the bed was sufficiently porous due to the lack of $-6.7 \mathrm{~mm}$ material to cause all water to infiltrate. Increasing the rainfall rate from 220 to $290 \mathrm{~mm} / \mathrm{h}$ did not significantly influence runoff proportion for the fine -6.7 to $0 \mathrm{~mm}$ particles. 


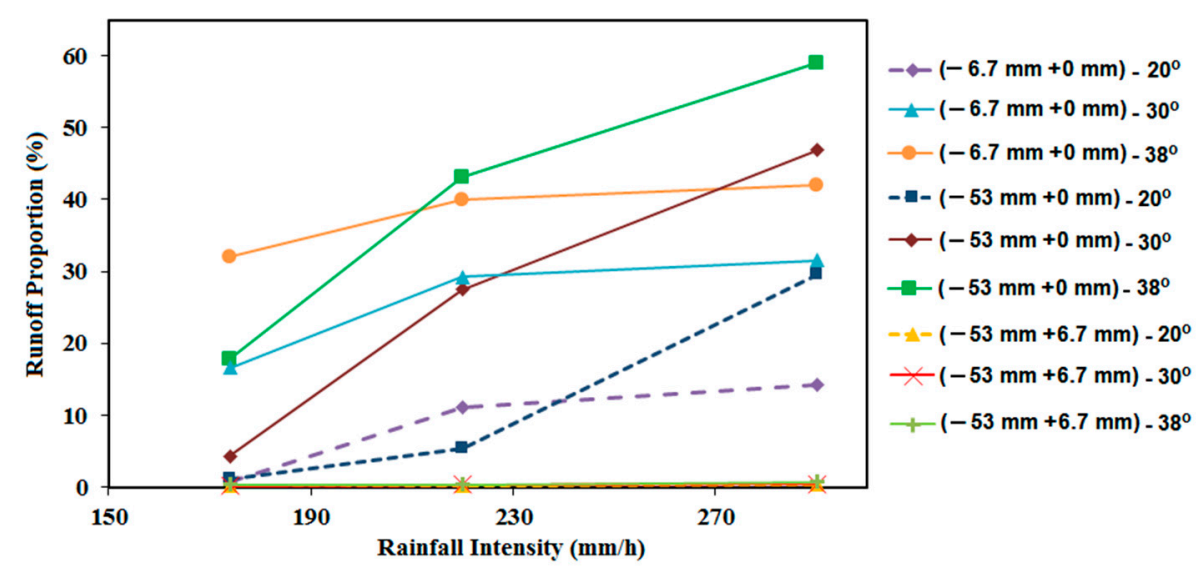

Figure 4. Proportion of runoff versus rainfall intensity.

\subsubsection{Effect of Slope Angle}

An increase in slope angle led to an increased runoff proportion, as shown in Figure 5. By increasing the slope angle, contact time between coal and water decreased, thus limiting the opportunity for infiltration. This effect was less pronounced for the porous and coarse coal beds.

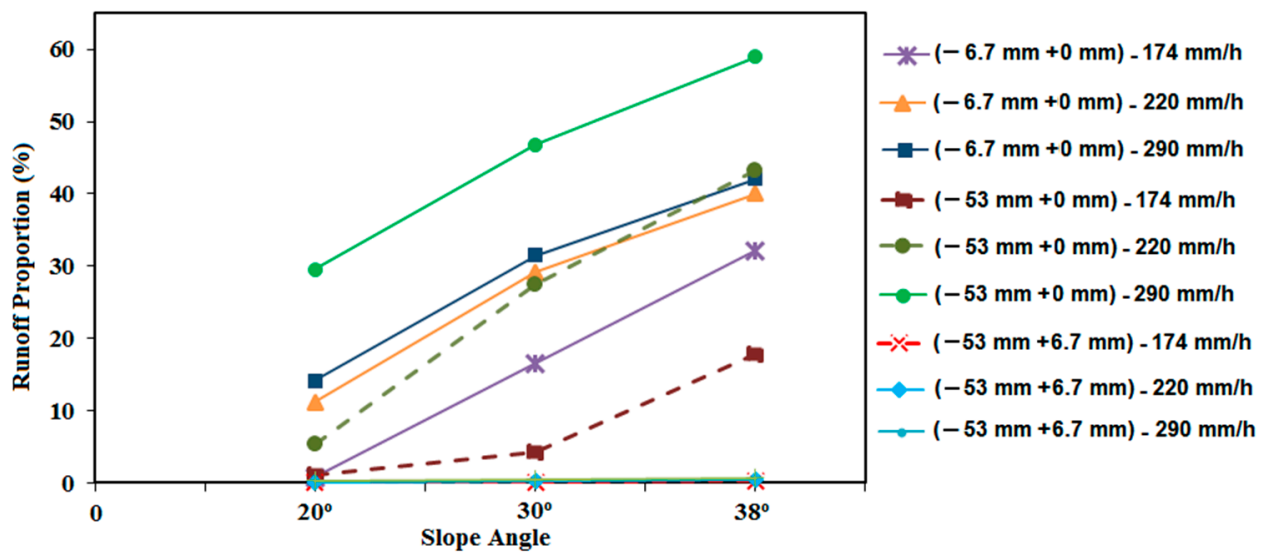

Figure 5. Proportion of runoff versus slope angle.

\subsubsection{Effect of Particle Size Distribution}

Runoff was strongly influenced by the fine-particle content (Figure 6). The coarse coal bed ( -53 to $6.7 \mathrm{~mm}$ ) had virtually no runoff, while the beds with more fines experienced surface runoff. This was due to decreased infiltration with the finer beds. The finest bed $(-6.7$ to $0 \mathrm{~mm}$ ) had the highest runoff proportions between a rainfall rate of 174 and $220 \mathrm{~mm} / \mathrm{h}$, while the maximal runoff occurred in the mixed bed at $290 \mathrm{~mm} / \mathrm{h}$.

As the rainfall event progressed, surface erosion, ponding, and channelling occurred (Figure 7). The probability of these disturbances increased with an increase in slope angle, rainfall intensity, and fine content.

During maximal rainfall intensity $(290 \mathrm{~mm} / \mathrm{h}$ ), the mixed size bed ( -53 to $0 \mathrm{~mm}$ ) had the tendency to form channels, while the fine bed $(-6.7$ to $0 \mathrm{~mm}$ ) had a predisposition towards pooling. The fine bed experienced significant erosion at high angles and high rainfall intensities. The coarse bed did not show any major form of surface disturbance. According to Roberts et al. [23], this can be explained by the difference in behaviour between large and small particles. Larger particles behave in a noncohesive manner, with particles individually eroding, while smaller particles tend to perform cohesively and eventually consolidate to erode in masses. 


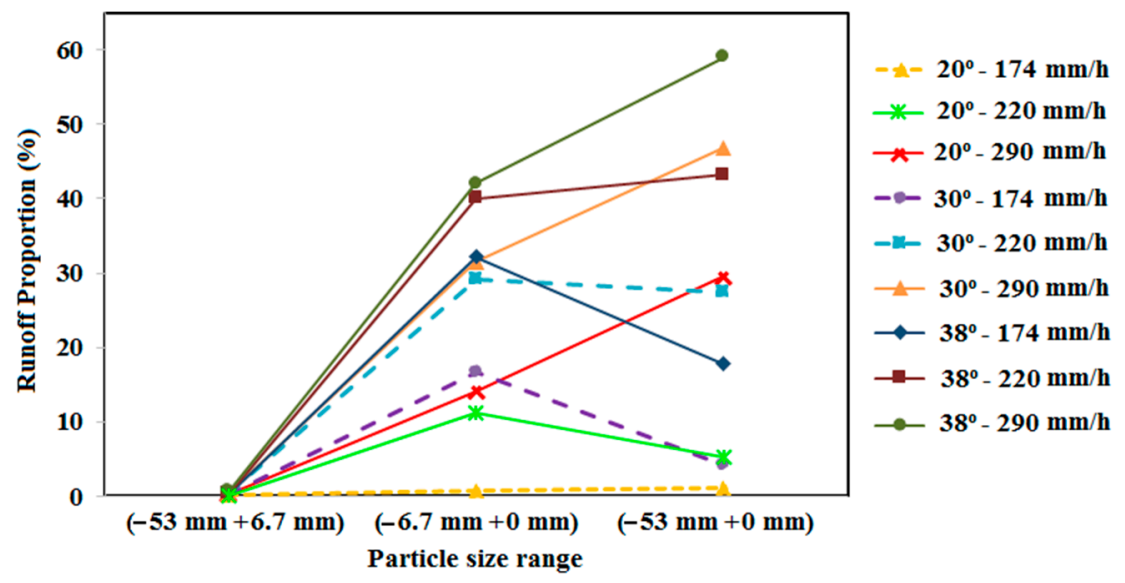

Figure 6. Proportion of runoff versus particle size range.

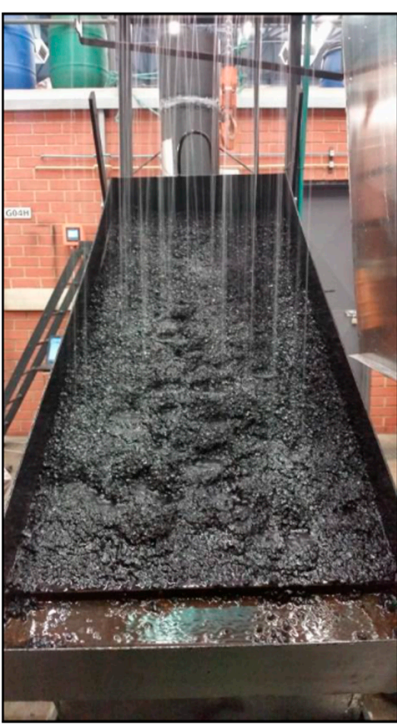

a

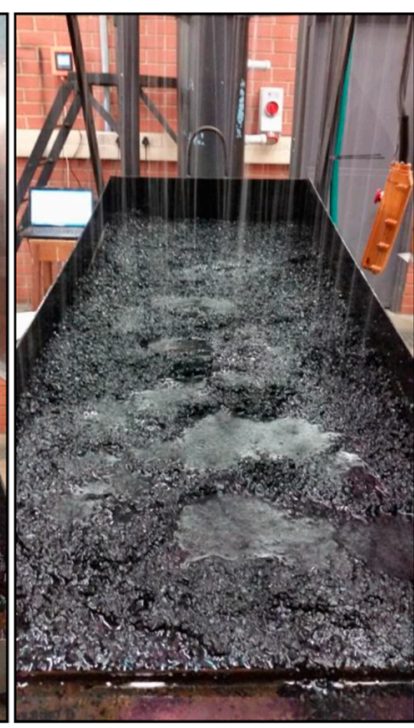

b

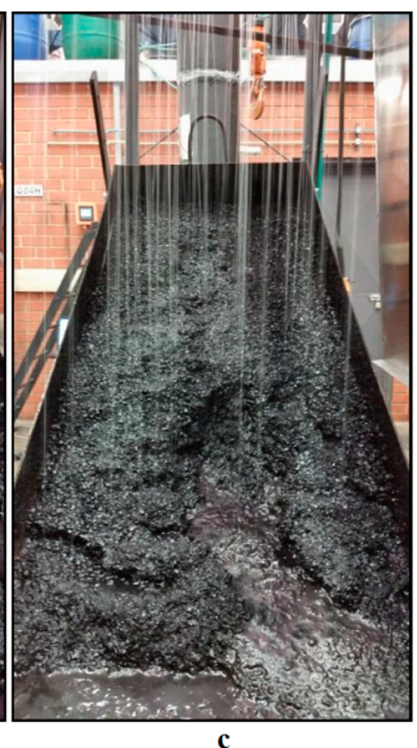

c

Figure 7. Surface disturbance. (a) Erosion; (b) ponding; (c) channelling.

\subsubsection{Degree of Compaction}

Since compaction decreases the voids between particles in the coal bed, this results in increased runoff (Figure 8). Therefore, by compacting a stockpile surface, most water ingress can be prevented. This is in accordance with recommendations by Ekmann and Le [24]. Results suggest that the effect of angle and rainfall intensity was less important than the degree of compaction was.

\subsection{Infiltration Rate}

According to the literature, the proportion of rainfall that infiltrates a stockpile surface is a function of both rainfall intensity and duration, and the coal bed's water infiltration capacity, which is determined by the bed's texture, structure, and initial moisture content $[25,26]$. Once saturation is achieved, any increase in rainfall intensity only leads to an increase in runoff, provided that the sample remains undisturbed. According to Figure 9, the infiltration capacity for fine and mixed beds decreased as the slope increased in the laboratory experiments. For the coarse bed ( -53 to $6.7 \mathrm{~mm}$ ), the infiltration rate was not influenced by the slope angle. It would be expected that an increase in rainfall intensity leads to a slight increase of the infiltration rate, but this was not seen for uncompacted coal beds $\left(997 \mathrm{~kg} / \mathrm{m}^{3}\right)$. This can be attributed to surface disturbances at high rainfall intensities and slop angles. It is apparent that the relationship between rainfall intensity and infiltra- 
tion rate is complex and irregular. In coarse beds, high rainfall intensity causes an increase in infiltration rate. In this case, no surface disturbance was observed. For the mixed size bed $(-53$ to $0 \mathrm{~mm})$ with a high slope angle and high rainfall intensity, infiltration rate decreased because of channelling. In the fine bed ( -6.7 to $0 \mathrm{~mm}$ ) with increasing rainfall intensity, infiltration rate increased because of ponding and creation of holes in the bed surface (Figure 10).

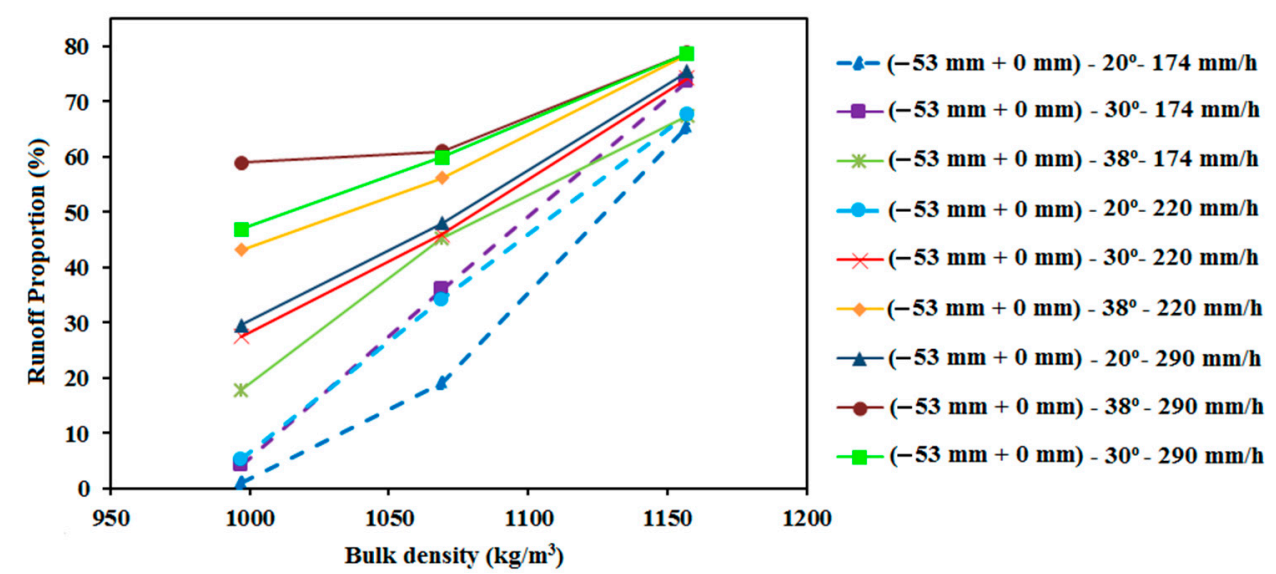

Figure 8. Proportion of runoff versus slope angle as a function of compaction.

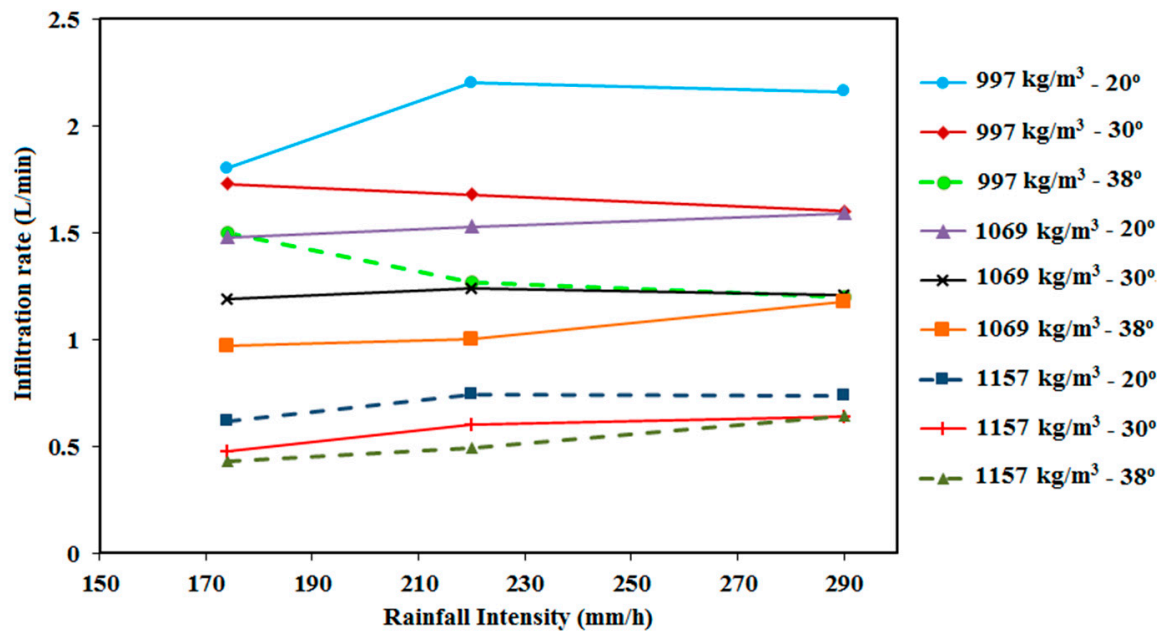

Figure 9. Infiltration rate versus rainfall intensity ( -53 to $0 \mathrm{~mm}$ ).

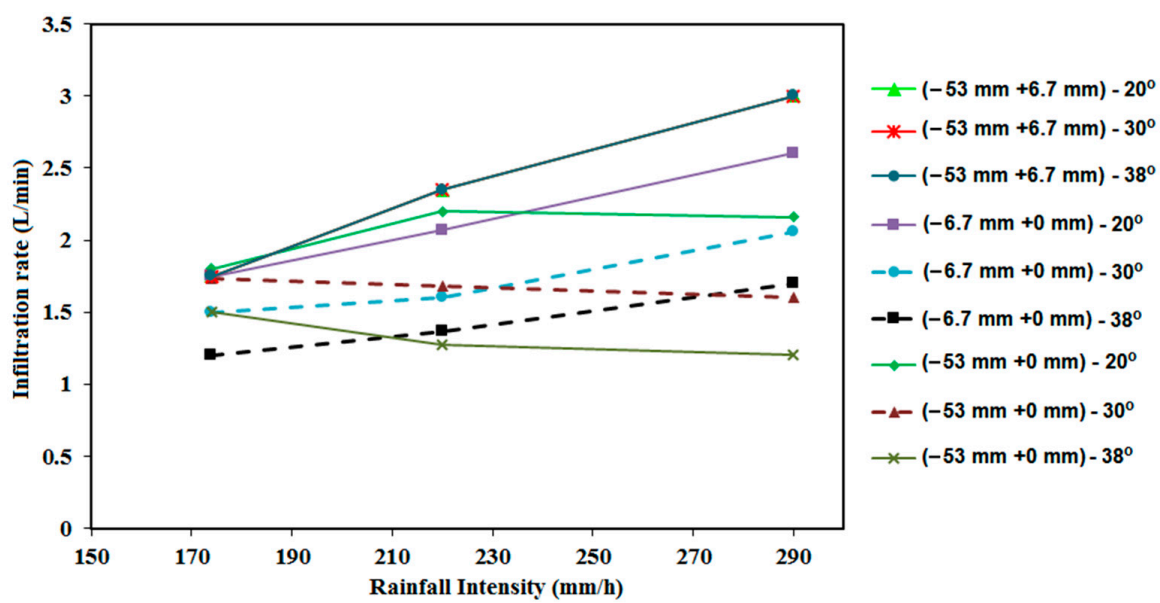

Figure 10. Infiltration rate versus rainfall intensity $\left(\rho=997 \mathrm{~kg} / \mathrm{m}^{3}\right)$. 


\subsection{Gravity Drainage}

\subsubsection{Effect of Bed Height}

The results of the influence of column height on drainage are summarised in Table 5. This shows that the height of a stockpile influences the amount of added water that drains out of coal. As the height of a stockpile increases, the weight of the coal above the bottom layer increases. This leads to an increase in pressure, which in turn aids in the drainage of water from the stockpile [8].

Table 5. Influence of stockpile height on drainage characteristics-experimental results (added water $20 \mathrm{~kg}-$ Coal A).

\begin{tabular}{cccc}
\hline Column Height $(\mathbf{m})$ & Size Range & $\boldsymbol{\rho}\left(\mathbf{k g} / \mathbf{m}^{\mathbf{3}}\right)$ & Retained Water $\mathbf{( k g )}$ \\
\hline \multirow{2}{*}{0.48} & \multirow{2}{*}{-53 to $0 \mathrm{~mm}$} & 1073 & 3.63 \\
& & 1073 & 4.27 \\
\multirow{2}{*}{2} & Average & & 3.95 \\
& \multirow{2}{*}{-53 to $0 \mathrm{~mm}$} & 1044 & 9.29 \\
& & 1054 & 9.51 \\
& & & 9.40 \\
\hline
\end{tabular}

\subsubsection{Effect of Degree of Compaction}

As seen in Table 6, the compaction of the coal bed from 1073 to $1198 \mathrm{~kg} / \mathrm{m}^{3}$ bulk density resulted in an average increase of $2.2 \%$ in the mass of retained moisture. By further compacting the bed into a bulk density of $1288 \mathrm{~kg} / \mathrm{m}^{3}$, the mass of retained moisture is increased by another $0.8 \%$.

Table 6. Influence of compaction on drainage (column height: $0.48 \mathrm{~m}$; added water: $20 \mathrm{~kg}$; size range: $(-53,+0 \mathrm{~mm})-$ Coal A).

\begin{tabular}{|c|c|}
\hline$\rho\left(\mathrm{kg} / \mathrm{m}^{3}\right)$ & Retained Water (kg) \\
\hline & 3.63 \\
\hline \multirow[t]{2}{*}{1073} & 4.27 \\
\hline & 3.78 \\
\hline \multirow[t]{2}{*}{ Average } & 3.89 \\
\hline & 4.17 \\
\hline \multirow[t]{2}{*}{1198} & 4.63 \\
\hline & 4.2 \\
\hline \multirow[t]{2}{*}{ Average } & 4.33 \\
\hline & 4.51 \\
\hline \multirow[t]{2}{*}{1288} & 4.06 \\
\hline & 4.93 \\
\hline Average & 4.5 \\
\hline
\end{tabular}

Changes in the total moisture content with bed height in the drainage experiments are presented in Figure 11. There was a clear difference between the total moisture content at the top and at the bottom of the noncompacted coal bed $\left(\rho=1073 \mathrm{~kg} / \mathrm{m}^{3}\right)$, but less so for the compacted coal beds $\left(\rho=1198 \mathrm{~kg} / \mathrm{m}^{3}\right.$ and $\left.\rho=1288 \mathrm{~kg} / \mathrm{m}^{3}\right)$. This indicated that the compaction of the samples largely prevented the percolation and movement of water because the bottom layer of a coal stockpile can be more compacted due to the weight of the coal above it. So, the bottom layer of the coal stockpile would be wetter than the above layers. 


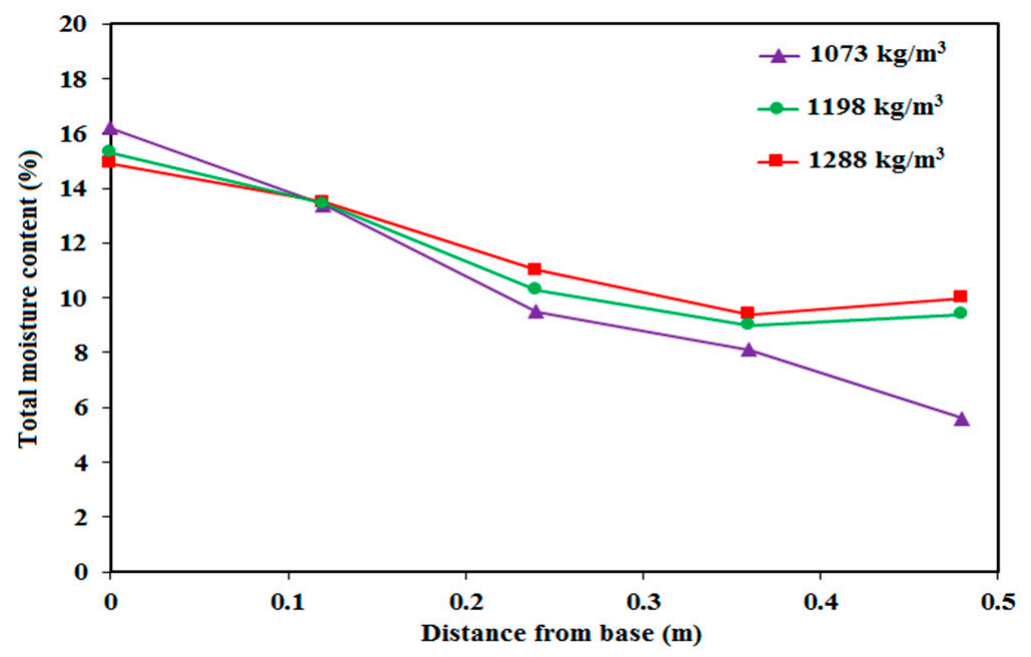

Figure 11. Moisture profile over $0.48 \mathrm{~m}$ high drainage column for different compactions (added water: $20 \mathrm{~kg}$; size range: $(-53,+0 \mathrm{~mm})-$ Coal A).

As water percolates through the coal bed, some fine particles are carried downwards with the flow of water. The size distribution of these migrating particles depends on the void size between the larger particles. As the degree of compaction increases, the void size between the particles decreases, thus allowing for fewer fine particles to migrate downwards with the added water. This is confirmed by the trends shown in Figure 12.

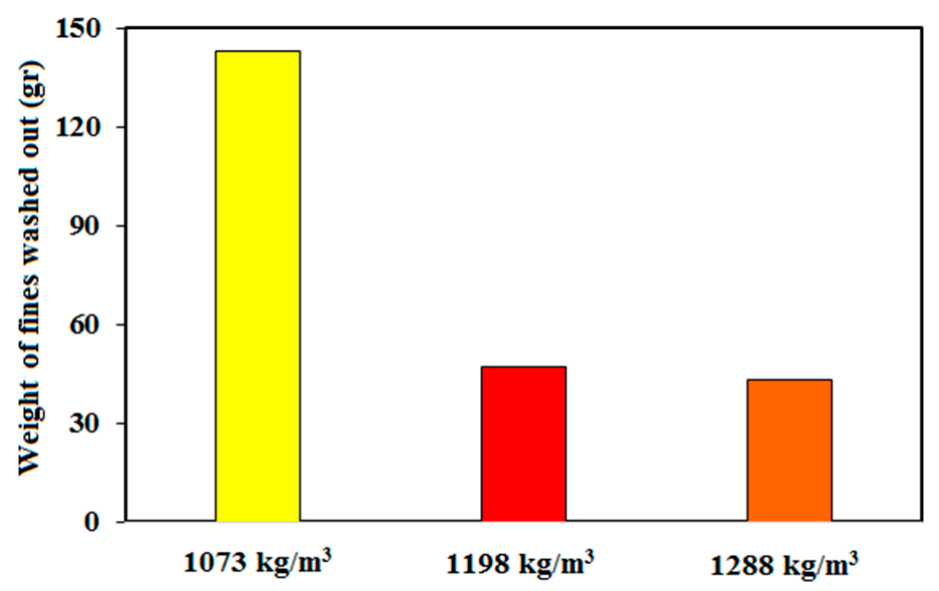

Figure 12. Weight of fines washed out of $0.48 \mathrm{~m}$ high drainage column.

\subsubsection{Effect of Particle Size Ranges}

The two drainage columns were also used to study the effect of particle size distribution on drainage characteristics. For the short $0.5 \mathrm{~m}$ drainage column, results are summarised in Table 7 . The presence of fine particles $(-0.5 \mathrm{~mm})$ inhibited the drainage of moisture from the coal bed, and the absence of fine particles translated into a decrease in the amount of retained water. This is further supported by the inclusion of a fine layer to the middle of the drainage column resulting in an increase in the amount of retained moisture (Figure 13). The thickness of the fine layer had a significant effect on the moisture holdup in that layer, but did not seem to affect the moisture in the rest of the bed. For the $2 \mathrm{~m}$ column, two different coal types with several different size ranges were used. A coal bed containing fewer fine particles retained less of the added water (Table 8), similar to the $0.5 \mathrm{~m}$ drainage column. 
Table 7. Influence of fines on $0.48 \mathrm{~m}$ drainage column-experimental results (coal A).

\begin{tabular}{|c|c|c|}
\hline Size Range & Layer of Fines & Retained Water (kg) \\
\hline-53 to $0 \mathrm{~mm}$ & Without layer of fines & $\begin{array}{l}3.63 \\
4.27\end{array}$ \\
\hline \multicolumn{2}{|c|}{ Average } & 3.95 \\
\hline-53 to $0.5 \mathrm{~mm}$ & Without layer of fines & $\begin{array}{l}2.99 \\
2.37\end{array}$ \\
\hline \multicolumn{2}{|c|}{ Average } & 2.68 \\
\hline-53 to $0 \mathrm{~mm}$ & $3 \mathrm{~cm}$ & $\begin{array}{l}3.86 \\
3.34\end{array}$ \\
\hline \multicolumn{2}{|c|}{ Average } & 3.60 \\
\hline \multirow[t]{2}{*}{-53 to $0 \mathrm{~mm}$} & $6 \mathrm{~cm}$ & $\begin{array}{l}4.91 \\
5.99\end{array}$ \\
\hline & & 5.45 \\
\hline
\end{tabular}

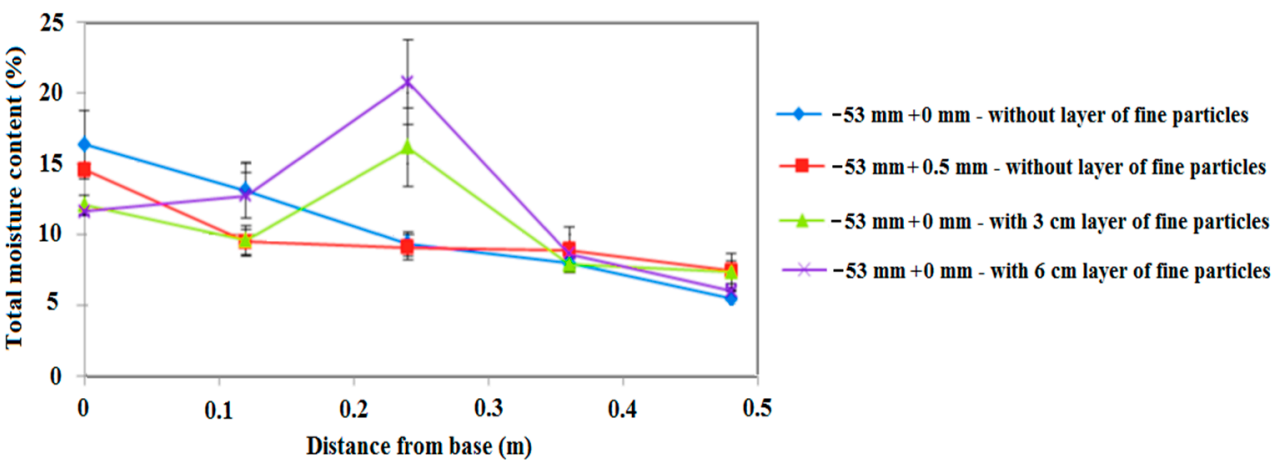

Figure 13. Moisture profile over $0.48 \mathrm{~m}$ high drainage column for different fine content (Coal A).

Table 8. Influence of fines on $2 \mathrm{~m}$ high drainage column-experimental results.

\begin{tabular}{|c|c|c|c|}
\hline Coal Type & Size Range & $\rho\left(\mathrm{kg} / \mathrm{m}^{3}\right)$ & Retained Water $(\mathrm{kg})$ \\
\hline \multirow{9}{*}{$\mathrm{A}$} & \multirow{2}{*}{-53 to $0 \mathrm{~mm}$} & 1029 & 9.29 \\
\hline & & 1044 & 9.51 \\
\hline & \multicolumn{2}{|c|}{ Average } & 9.40 \\
\hline & \multirow{3}{*}{-53 to $0.5 \mathrm{~mm}$} & 1012 & 8.00 \\
\hline & & 985 & 8.20 \\
\hline & & & 8.1 \\
\hline & \multirow{4}{*}{-53 to $1 \mathrm{~mm}$} & 989 & 7.88 \\
\hline & & 1024 & 7.67 \\
\hline & & & 7.77 \\
\hline \multirow{12}{*}{ B } & & 879 & 3.85 \\
\hline & \multirow[t]{2}{*}{53 to $0 \mathrm{~mm}$} & 879 & 3.78 \\
\hline & & 879 & 4.68 \\
\hline & \multicolumn{2}{|c|}{ Average } & 4.1 \\
\hline & \multirow{3}{*}{-53 to $6.7 \mathrm{~mm}$} & 659 & 0.88 \\
\hline & & 659 & 1.20 \\
\hline & & 659 & 2.16 \\
\hline & \multicolumn{2}{|c|}{ Average } & 1.41 \\
\hline & \multirow{4}{*}{-6.7 to $0 \mathrm{~mm}$} & 743 & 6.41 \\
\hline & & 743 & 5.07 \\
\hline & & 743 & 5.01 \\
\hline & & & 5.49 \\
\hline
\end{tabular}


Figure 14 displays the drainage profiles for the two coals. For Coal A (Figure 14a), the exclusion of the $-0.5 \mathrm{~mm}$ particles had a much larger effect than that of the exclusion of $-1 \mathrm{~mm}$ particles on the final retained water mass. This indicates that drainage-related problems depend on the $-0.5 \mathrm{~mm}$ fraction. This was similar for Coal B (Figure 14b). The coarse coal sample ( -53 to $6.7 \mathrm{~mm}$ ) drained almost instantaneously and retained very little of the added water. In contrast, the mixed sample $(-53$ to $0 \mathrm{~mm})$ and the fine sample ( -6.7 to $0 \mathrm{~mm}$ ) retained approximately $20 \%$ of the added water. The mixed and fine samples also drained at a much slower rate than the coarse sample did due to the difference in void spaces within the coal bed. As mentioned in the literature, a decrease in particle size translates into fewer interstitial voids that inhibit the movement of moisture [8].
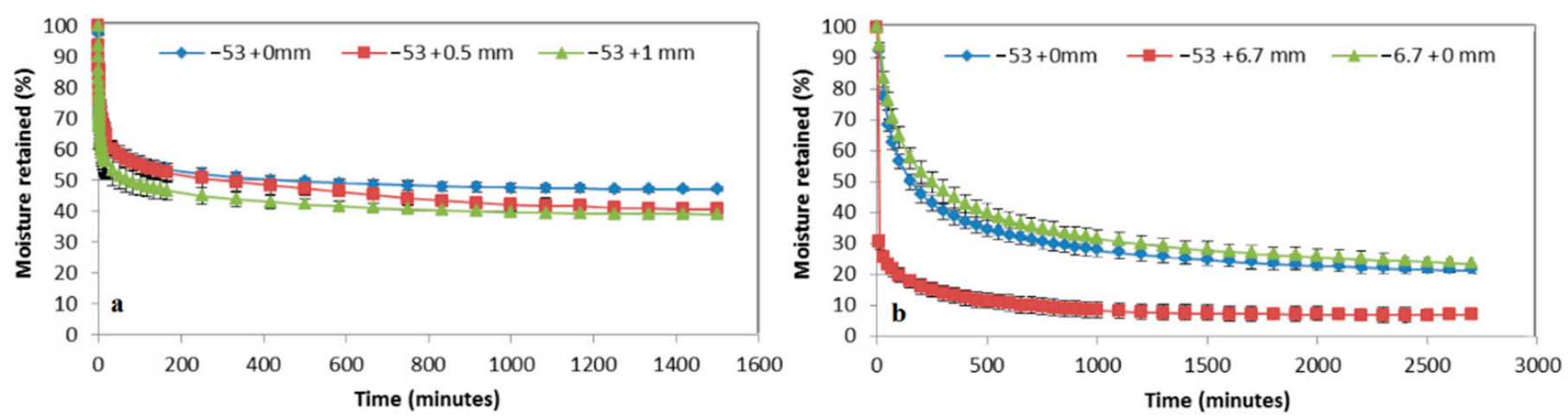

Figure 14. Average drainage profiles of $2 \mathrm{~m}$ drainage column for Coals (a) A and (b) B.

Changes in the moisture profiles over time in the case of Coal B for two different particle size distributions are given in Figure 15. Values on Day 0 represent the total moisture prior to any water addition into the top of the column, and all drainage had ceased by the time the sample on Day 2 was taken. The profile of the coarse particles shows that the coal bed retained very little of the added water, showing the ease with which extra water drains out (Figure 15a). This is in contrast with the profile obtained for the fine coal (Figure 15b). Some water was retained by the coal bed, explaining the increase in moisture content from Day 0 to Day 2. This "region of wetness" gradually migrated downwards over time, towards the bottom section of the drainage column. No water exited the column after the second day, even during this downward migration of moisture.
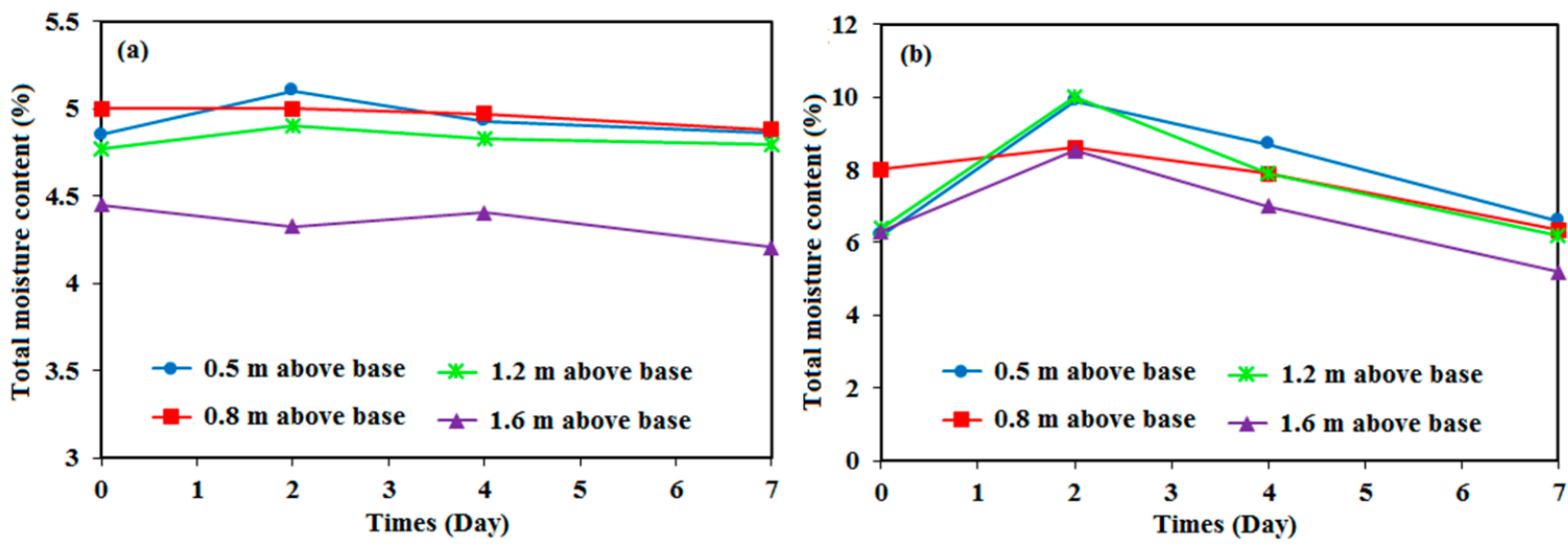

Figure 15. Moisture profile of Coal B sample in $2 \mathrm{~m}$ drainage column: (a) -53 to $6.7 \mathrm{~mm}$; (b) -6.7 to $0 \mathrm{~mm}$. 


\subsubsection{Effect of Coal Type}

Obtained values in Table 8 for Coals A and B show that coal type also influences drainage. Coal A retained a larger portion of the added $20 \mathrm{~kg}$ of water when compared to the amount retained by Coal B. Coal A is high-ash coal, which means that it was more likely to retain moisture when compared to lower-ash coal such as Coal B. Clay minerals have stronger moisture retention than that of other minerals.

\subsubsection{Data Validation}

Since there was no uniform structure within the drainage column due to variability and heterodisperse particles, the representative sample in the $2 \mathrm{~m}$ high drainage column was difficult. It was thus necessary to validate the moisture profiles obtained by means of mass balances. The drainage pipe was divided into four sections, and each sample was assumed to be representative of its section as a whole. The initial moisture content of the sections and the decrease in total coal mass over time as a result of sampling were taken into account. A mass balance over each section is calculated by Equations (1) and (2):

$$
\begin{gathered}
\text { Water mass flow out }=(\text { water mass flow in })-(\text { water mass accumulated }) \\
\text { Water mass accumulated }=(\text { water mass before })-(\text { water mass after })
\end{gathered}
$$

The mass balance schematic over the $2 \mathrm{~m}$ drainage column is shown in Figure 16. Table 9 shows the mass balance obtained for the coarse coal sample ( -53 to $6.7 \mathrm{~mm}$ ) experiment. There was a slight difference between the calculated amount of water that exited the drainage pipe and the actual amount that was measured. This could be attributed to accurate sampling being difficult in such an experimental setup. According to mass balance, $2.12 \mathrm{~kg}$ of water should exit the column by the end of the second day, which was not seen in the measured values. This discrepancy could be because the bottom sampling port was $0.5 \mathrm{~m}$ from the base of the column, which means that the calculated $2.12 \mathrm{~kg}$ of water could have drained undetected into the bottom section of the column that was unable to exit as a result of the increased fine content at the base of the packed bed. This experimental error is considered to be extremely good for experimental setups such as this. These results confirm the validity of the moisture profiles and the method of sampling.

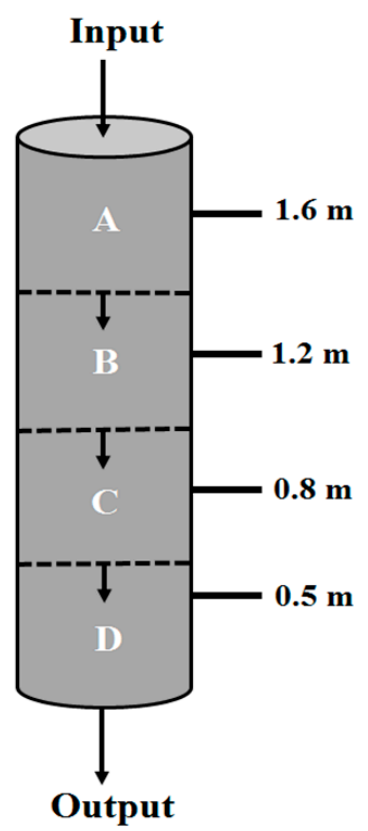

Figure 16. Mass balance over $2 \mathrm{~m}$ drainage column. 
Table 9. Mass balance for -53 to $6.7 \mathrm{~mm}$ Coal B sample in $2 \mathrm{~m}$ high drainage column.

\begin{tabular}{|c|c|c|c|c|c|c|c|c|}
\hline $\begin{array}{l}\text { Time } \\
\text { Period }\end{array}$ & Position & Input (kg) & $\begin{array}{c}\text { Initial } \\
\text { Mass (kg) }\end{array}$ & $\begin{array}{c}\text { Final Mass } \\
(\mathrm{kg})\end{array}$ & $\begin{array}{l}\text { Accumulated } \\
(\mathrm{kg})\end{array}$ & Output (kg) & $\begin{array}{l}\text { Actual out } \\
\text { (kg) }\end{array}$ & $\begin{array}{l}\text { Difference } \\
\quad(\mathrm{kg})\end{array}$ \\
\hline \multirow{4}{*}{$\begin{array}{c}\text { Days } 0-2 \\
\text { ( } 2 \text { days) }\end{array}$} & A & 20.00 & 2.4 & 2.81 & 0.41 & 19.59 & & \\
\hline & B & 19.59 & 2.67 & 1.92 & -0.75 & 20.34 & & \\
\hline & $\mathrm{C}$ & 20.34 & 2.81 & 2.23 & -0.58 & 20.92 & & \\
\hline & $\mathrm{D}$ & 20.92 & 2.44 & 2.72 & 0.28 & 20.64 & 18.52 & 2.12 \\
\hline \multirow{4}{*}{$\begin{array}{l}\text { Days } 2-4 \\
\text { ( } 2 \text { days) }\end{array}$} & A & 0.00 & 2.81 & 2.24 & -0.57 & 0.57 & & \\
\hline & B & 0.57 & 1.92 & 2.32 & 0.4 & 0.17 & & \\
\hline & $\mathrm{C}$ & 0.17 & 2.81 & 2.30 & 0.08 & 0.09 & & \\
\hline & $\mathrm{D}$ & 0.09 & 2.72 & 2.71 & 0.02 & 0.02 & 0.00 & 0.02 \\
\hline \multirow{4}{*}{$\begin{array}{l}\text { Days } 4-7 \\
\text { ( } 3 \text { days) }\end{array}$} & $\mathrm{A}$ & 0.00 & 2.24 & 1.96 & -0.28 & 0.28 & & \\
\hline & B & 0.28 & 2.32 & 2.24 & -0.08 & 0.08 & & \\
\hline & $\mathrm{C}$ & 0.08 & 2.30 & 2.27 & -0.03 & 0.03 & & \\
\hline & $\mathrm{D}$ & 0.03 & 2.71 & 2.48 & -0.23 & 0.23 & 0.00 & 0.23 \\
\hline
\end{tabular}

\section{Conclusions}

This study described and compared changes in coal moisture content following rainfall events within a stockpile. This study examined the processes of runoff, infiltration, and drainage by which moisture migrates or is retained in a coal stockpile. The following outcomes from Part 1 of the research work are summarised:

- There was a positive relationship between the proportion of surface runoff, and rainfall intensity, angle of repose, fine content, and the degree of compaction. Results indicated that the final rate of infiltration is dependent on the characteristics of the stockpile surface. A stockpile consisting of coarse particles has much larger infiltration capacity. A smaller angle of repose results in longer contact time between stockpile surface and water, which increases the proportion of rainfall that infiltrates the stockpile. A decrease in the size of interparticulate voids (either through compaction or high fine content) leads to increased surface runoff. To minimise infiltration, stockpile surfaces should be compacted at an angle that minimises the contact time between surface and water, reducing the possibility of erosion occurring.

- Results confirmed that particle size distribution (PSD) plays a large role in determining the extent to which a coal stockpile is dewatered by means of drainage. The $-0.5 \mathrm{~mm}$ particles had a large effect on the amount of water retained by a coal sample. Increased stockpile height positively influences the degree of dewatering. A comparison between the drainage profiles of the two coal types studied in this investigation showed that high ash and clay mineral content leads to more water being retained by the coal stockpile. It may thus be more difficult to dewater certain coals by means of gravity drainage.

- In Part 2 of this work, the effect of coal particle size and ambient conditions on the rate and depth of moisture evaporation within the stockpile will be reported.

Author Contributions: Conceptualisation, Q.P.C. and M.1.R.; supervision, Q.P.C.; methodology, Q.P.C.; testing and analysis, Q.P.C., M.1.R. and F.N.; writing—original draft preparation, F.N.; writingreview and editing, F.N. and Q.P.C. All authors have read and agreed to the published version of the manuscript.

Funding: This research was funded by [Coaltech Research Association NPC] and [the South Africa National Research Foundation THRIP programme] grant number [TP14081289982] and The APC was funded by North West University.

Data Availability Statement: Data sharing is not applicable. 
Acknowledgments: The authors would like to acknowledge the support of Coaltech and Eskom for this research.

Conflicts of Interest: The authors declare no conflict of interest.

\section{References}

1. Zhu, H.; Zhang, Y.; Qu, B.; Liao, Q.; Wang, H.; Gao, R. Thermodynamic characteristics of methane adsorption about coking coal molecular with different sulfur components: Considering the influence of moisture contents. J. Nat. Gas Sci. Eng. 2021, $94,104053$. [CrossRef]

2. Liu, L.; Cheng, L.; Zhao, L.T.; Cao, Y.; Wang, C. Investigating the significant variation of coal consumption in china in $2002-2017$. Energy 2020, 207, 118307. [CrossRef]

3. Hartnady, C. South Africa's diminishing coal reserves. S. Afr. J. Sci. 2010, 106, 1-5. [CrossRef]

4. South African Energy Sector Report 2019. Available online: http://www.energy.gov.za/files/media/explained/2019-SouthAfrican-Energy-Sector-Report.pdf (accessed on 5 April 2021).

5. Campbell, Q.P.; Le Roux, M.; Smith, I.G.T. Water-only laboratory coal fractionation using the reflux classifier. Miner. Eng. 2015, 83, 59-63. [CrossRef]

6. Buckley, A.N.; Nicol, S.K. Investigation Report CET/IR273: Surface-Related Moisture Retention Characteristics of Coal; CSIRO: Sydney, Australia, 1995.

7. Karthikeyan, M. Minimization of moisture readsorption in dried coal samples. Dry. Technol. 2008, 26, 948-955. [CrossRef]

8. Nkolele, A. Investigations into the reduction of moisture in fine coal by plant tests with surfactants. J. S. Afr. Inst. Min. Metall. 2004, 104, 171-176.

9. Mao, Y.; Xia, W.; Xie, G.; Peng, Y. Rapid detection of the total moisture content of coal fine by low-field nuclear magnetic resonance. Measurement 2020, 155, 107564. [CrossRef]

10. Williams, D.J. Application of unsaturated soil mechanics to product coal dewatering. In Proceedings of the 2006 Australian Mining Technology Conference, Hunter Valley, NSW, Australia, 26-27 September 2006; pp. 223-235.

11. Osman, H.; Jangam, S.V.; Lease, J.D.; Mujumdar, A.S. Drying of low-rank coal (LRC)—A review of recent patents and innovations. Dry. Technol. 2011, 29, 1763-1783. [CrossRef]

12. Lu, H.; Guo, X.; Jin, Y.; Gong, X. Effect of moisture on flowability of pulverized coal. Chem. Eng. Res. Des. 2018, 133, 326-334. [CrossRef]

13. Curran, K.J.; Droppo, I.G.; Irvine, K.N. Hydrology of stockpiled industrial coal exposed to rainfall. Hydrol. Process. 2002, 16, 2781-2790. [CrossRef]

14. Campbell, Q.; Le Roux, M.; Espag, C. Coal product moisture control using stockpiles. In Proceedings of the XVIII International Coal Preparation Congress, Saint-Petersburg, Russia, 28 June-1 July 2016; Litvinenko, V., Ed.; Springer: Cham, Switzerland, 2016. [CrossRef]

15. Le Roux, M.; Campbell, Q.P. An investigation into an improved method of fine coal dewatering. Miner. Eng. 2003, 16, 999-1003. [CrossRef]

16. Le Roux, M.; Campbell, Q.P.; Watermeyer, M.S.; de Oliveira, S. The optimization of an improved method of fine coal dewatering. Miner. Eng. 2005, 18, 931-934. [CrossRef]

17. Goede, J.; Muller, B.; Campbell, Q.P.; Le Roux, M.; Espag, C.B. The effect of particle size on the rate and depth of moisture evaporation from coal stockpiles. J. S. Afr. Inst. Min. Metall. 2016, 116, 353-355. [CrossRef]

18. Zhang, J.; Ren, T.; Liang, Y.; Wang, Z. A review on numerical solutions to self-heating of coal stockpile: Mechanism, theoretical basis, and variable study. Fuel 2016, 182, 80-109. [CrossRef]

19. Davis, E.C.; Boegly, W.J. A review of water quality issues associated with coal storage. J. Environ. Qual. 1981, 10, 127-133. [CrossRef]

20. Agassi, M.; Shainberg, I.; Morin, J. Effect of electrolyte concentration and soil sodicity on the infiltration rate and crust formation. Soil Sci. Soc. Am. J. 1981, 45, 848-851. [CrossRef]

21. Huang, P.; Wu, P.; Zhao, X. Effects of rainfall intensity, underlying surface and slope gradient on soil infiltration under simulated rainfall experiments. Catena 2012, 104, 93-102. [CrossRef]

22. Luo, H.; Rong, Y.; Lv, J.; Xie, Y. Runoff erosion processes on artificially constructed conically-shaped overburdened stockpiles with different gravel contents: Laboratory experiments with simulated rainfall. CATENA 2019, 175, 93-100. [CrossRef]

23. Roberts, J.; Jepsen, R.; Gotthard, D.; Lick, W. Effects of particle size and bulk density on erosion of quartz particles. J. Hydraul. Eng. 1998, 124, 531-538. [CrossRef]

24. Ekmann, J.M.; Le, P.H. Coal Storage and Transportation. Encycl. Energy 2014, 1, 557-558.

25. Wels, C.; Louden, S.; Fortin, S. Factors Influencing Net Infiltration into Mine Rock Piles at Questa Mine New Mexico. Available online: https://www.rgc.ca/files/publications/welfin.pdf (accessed on 8 August 2015).

26. Espag, C. Water Transport Mechanisms in Coal Stockpiles. Master's Thesis, North-West University, Potchefstroom, South Africa, 2015; p. 14. 